\title{
Spectral light absorption and quantum yield of photosynthesis in sea ice microalgae and a bloom of Phaeocystis pouchetii from McMurdo Sound, Antarctica
}

\author{
J. Beeler SooHoo ${ }^{1}$, A. C. Palmisano ${ }^{2}$, S. T. Kottmeier ${ }^{3}$, M. P. Lizotte ${ }^{3}$, S. L. SooHoo ${ }^{4}$, \\ C. W. Sullivan ${ }^{3}$ \\ 1 Allan Hancock Foundation, University of Southern California, Los Angeles, California 90089-0371, USA \\ ${ }^{2}$ NASA Ames Research Center, Mail Stop 239-4, Moffet Field, California 94035, USA \\ ${ }^{3}$ Marine Biology Research Section, Department of Biological Sciences, University of Southern California, Los Angeles, \\ California 90089-0371, USA \\ ${ }^{4}$ Scientific Data Center, Cedars-Sinai Medical Center, Los Angeles, California 90048, USA
}

\begin{abstract}
Ab STRACT: Spectral irradiance, in vivo absorption spectra and quantum yield of photosynthesis $(\Phi)$ were measured in December 1984 for both congelation ice and platelet ice microalgae and for a bloom of the planktonic prymnesiophyte Phaeocystis pouchetii from McMurdo Sound, Antarctica. Profiles of spectral irradiance through the ice column demonstrated that the irradiance environment of sea ice was vertically and horizontally heterogeneous, changing from blue-dominated to green-dominated with depth in the column, and varying from site to site depending on snow cover and ice algal patchiness. In response to reductions in irradiance, platelet ice microalgae consistently showed enhanced absorption of blue-green light relative to congelation ice microalgae. Samples of the planktonic alga $P$. pouchetii from under the seasonal fast ice of McMurdo Sound also exhibited enhanced blue-green absorption relative to samples from open waters of the Ross Sea. The mean specific absorption coefficient, ${ }^{\circ}$, for sea ice microalgae ranged between 0.0058 and $0.0097 \mathrm{~m}^{2}(\mathrm{mg} \mathrm{chl} \mathrm{a})^{-1}$, values characteristic of microalgae in green productive waters. For $P$. pouchetii, ${ }^{\circ} \bar{a}$ was greatest for samples taken from open water at the ice edge $\left(0.015\right.$ to $0.029 \mathrm{~m}^{2}[\mathrm{mg} \mathrm{chl} \mathrm{a}]^{-1}$ ), and decreased to about $0.008 \mathrm{~m}^{2}$ (mg chl a) ${ }^{-1}$ for samples taken from under the seasonal ice of McMurdo Sound. The quantum yield of photosynthesis for these microalgae ranged from 0.013 to $0.055 \mathrm{~mol} \mathrm{C}$ (Ein absorbed $)^{-1}$, and no significant differences in $\Phi$ were found between congelation ice and platelet ice algae.
\end{abstract}

\section{INTRODUCTION}

In McMurdo Sound, Antarctica, microalgal assemblages composed almost exclusively of diatoms are found both near the bottom of the hard congelation ice and in the underlying platelet ice layer when it is present (Lewis \& Weeks 1970, Sullivan \& Palmisano 1981, Palmisano \& Sullivan 1983). Several studies suggest that light is the limiting factor to sea ice microalgal growth (Bunt 1971, Fogg 1977, Horner \& Schrader 1982, Palmisano \& Sullivan 1982, Sullivan et al. 1983). Sullivan et al. (1985), Grossi et al. (1987) and Gosselin et al. (1985) have found inverse correlations between snow cover and ice microalgal abundance in the Antarctic and Arctic respectively. During the ice microalgal bloom of the austral spring, under-ice irradiance is generally less than $1 \%$, and sometimes less than $0.1 \%$, of incident surface irradiance (Sullivan et al. 1983, 1984, Palmisano et al. 1987a). Despite the limited availability of light, standing stocks of sea ice micro-

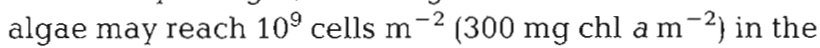
fast ice of McMurdo Sound (Palmisano \& Sullivan 1983, Sullivan et al. 1983). This value of chl a represents $75 \%$ of the theoretical maximum yield for diatom populations (Steemann-Nielsen 1962). During a bloom of the prymnesiophyte Phaeocystis pouchetii in the water column of McMurdo Sound during December 1984, cell densities reached $2.9 \times 10^{7}$ cells $^{-1}$ and the phytoplankton chl a concentration reached $12 \mu \mathrm{gl}^{-1}$ in the water column under the annual sea ice (Palmisano et al. 1986).

The presence of such large standing stocks of mi- 
croalgae in the congelation ice layer affects not only the quantity of light available to microalgae in the underlying platelet layer and the phytoplankton in the water column, but also the spectral composition of that light (Maykut \& Grenfell 1975, Sullivan et al. 1984). Morel (1978) discussed the relationships between available, usable, and stored radiant energy and marine photosynthesis. Photosynthetically available radiation (PAR) is defined as the amount of radiant energy available within the approximate spectral range of 350 to $750 \mathrm{~nm}$ (Tyler 1966). Instruments commonly used in studies of marine photosynthesis are PAR meters; that is, they report ${ }_{400} \int^{700} \mathrm{I}_{(\lambda)}$ or total PAR. Photosynthetically usable radiation (PUR) is defined as the fraction of photosynthetically available radiant energy of such wavelengths that it can be absorbed by the microalgal pigments. Light is selectively absorbed by most microalgae in the blue and red regions of the spectrum, causing the transmitted light to be concentrated in regions of the spectrum where algal pigment systems are ineffective at trapping light for photosynthesis (Sullivan et al. 1984). PUR is necessarily less than PAR, and PUR will depend on both the pigment complement of the microalgae and the spectral composition of the available submarine radiant energy.

How can blooms of sea ice microalgae and under-ice phytoplankton reach such high densities when so little light is available for photosynthesis? Several studies have investigated the photosynthesis-irradiance parameters of sea ice microalgae and concluded that these microalgae are highly shade adapted, with photosynthesis saturating at 2 to $10 \mu \mathrm{Ein}^{-2} \mathrm{~s}^{-1}$, and may even be photoinhibited at some naturally-occurring light levels (Bunt 1963, Cota 1985, Palmisano et al. 1985). Palmisano et al. (1986) demonstrated that Phaeocystis pouchetii is able to adapt to the reduced growth irradiance it encounters when it is advected from the ice-free waters of the Ross Sea where blooms of this alga occur (El-Sayed et al. 1983) to under the seasonal ice of McMurdo Sound. It achieves this by increasing the efficiency of light utilization $(\alpha)$, measured by the slope of the light-limited portion of the photosynthesisirradiance curves, by a factor of 4 . One might hypothesize that these microalgae, like phytoplankton from near the bottom of the euphotic zone, adapt physiologically in ways that enable them to photosynthesize with maximal quantum yields.

The quantum yield of photosynthesis ( () ), defined as gross production (measured either as moles of $\mathrm{CO}_{2}$ fixed or $\mathrm{O}_{2}$ produced) per mole of absorbed light, has been evaluated for laboratory cultures of microalgae (Manning et al. 1938, Emerson \& Lewis 1943, Govindjee et al. 1968, Ng \& Bassham 1968, Welschmeyer \& Lorenzen 1981); for phytoplankton from a variety of water types (Tyler 1975, Dubinsky \& Berman 1976.
Morel 1978, Tilzer 1983, 1984, Meffert \& Overbeck 1985, Kishino et al. 1986); for Antarctic phytoplankton (Tilzer et al. 1985, 1986); and for benthic marine macroalgae (Dring \& Lüning 1985, Lüning \& Dring 1985). To date, no measurements of $\Phi$ for sea ice microalgae or the cosmopolitan prymnesiophyte Phaeocystis pouchetii have been reported in the literature.

Assemblages of sea ice microalgae facilitate the study of spectral light absorption and photosynthetic quantum yield for several reasons. First, during the ice algal bloom in the austral spring (October to December), ice microalgae are abundant and the same assemblage is easy to sample repetitively. Second, the sea ice algal assemblages in McMurdo Sound are almost exclusively diatoms and these assemblages are usually dominated by few species (Grossi \& Sullivan 1985). Therefore, only one major complement of photosynthetic pigments is present - chlorophylls $a_{1} c_{1}$ and $c_{2}$, with fucoxanthin as the major xanthophyll. This simplifies interpretation of in vivo absorption spectra and in situ spectral irradiance profiles and eliminates the combined effects of absorption properties of various algal pigment groups usually present in the plankton (Yentsch \& Yentsch 1979, Kiefer \& SooHoo 1982, Neori et al. 1984, SooHoo et al. 1986). Finally, confinement of microalgae to the congelation ice layer or the platelet ice layer precludes vertical mixing, reducing light history considerations by at least one dimension (Lewis et al. 1984).

Similarly, the early summer bloom of Phaeocystis pouchetii in McMurdo Sound provided a unique opportunity for conducting an essentially unialgal experiment in situ. During the December 1984 bloom, more than $99 \%$ of phytoplankton belonged to this genus (Palmisano et al. 1986), making it feasible to attribute the results obtained with natural samples to $P$. pouchetii alone.

Several models of microalgal production include $\Phi$ and potential absorption per unit of phytoplankton chl $a$, represented by the mean specific absorption coefficient $\left({ }^{\circ} \bar{a}\right)$, as fundamental parameters of photosynthesis (Bannister 1974, Baumert \& Uhlmann 1983, Côté \& Platt 1983, Fasham \& Platt 1983, Kiefer \& Mitchell 1983). In these models, $\Phi$ is generally expressed as a function of irradiance, and ${ }^{\circ} \bar{a}$ is often assigned a constant value in spite of the well-documented effects of spectral composition on its value (Morel 1978, Bannister \& Weidemann 1984). Because sea ice microalgae may contribute 25 to $66 \%$ of total primary production in polar regions (Alexander 1974, Hoshiai 1981, Grossi et al. 1987), it would be useful to apply such models to this component of the polar ecosystems. Determination of the quantum yield of photosynthesis and an understanding of variability in absorption properties of sea ice microalgae are important in evaluating the applica- 
bility of such models of photosynthesis to annual cycles of primary production of sea ice microalgae and phytoplankton in McMurdo Sound.

The purpose of this study was to measure spectral light absorption and quantum yield of photosynthesis for sea ice microalgae collected from several sites around McMurdo Sound, Antarctica, and for a bloom of the prymnesiophyte Phaeocystis pouchetii that occurred in the water column under the seasonal fast ice there. We believe that our data represent the first published measurements of ${ }^{\circ} \overline{\mathrm{a}}$ and $\Phi$ for both sea ice microalgae and $P$. pouchetii.

\section{METHODS}

Sample collection. Samples of ice microalgae and phytoplankton were collected at 10 sites in McMurdo Sound, Antarctica during December 1984 (Fig. 1).

Samples of congelation ice microalgae were collected by first drilling through approximately $1.3 \mathrm{~m}$ of sea ice with a gasoline-powered Jiffy drill and then using a Sipre auger to collect the lowermost $0.7 \mathrm{~m}$ containing the microalgae. We carefully shielded the ice core with an opaque black tarp while it was being brought to the surface of the ice and during subsequent manipulations to prevent exposure of the ice microalgae to surface irradiance. Ice containing microalgae was scraped from the bottom portion of a core into filtered sea water at $-2{ }^{\circ} \mathrm{C}$. If the sample was to be returned to the laboratory, it was transported in a Polyfoam freeze-safe container at 0 to $-2{ }^{\circ} \mathrm{C}$.

Samples of the platelet ice algal community were collected from the interstitial water of the platelet ice layer by SCUBA divers using Nalgene containers. The divers surfaced with the samples within a darkened dive hut, so samples were never exposed to bright surface sunlight. Samples were transported to the laboratory in a Polyfoam freeze-safe container at 0 to $-2^{\circ} \mathrm{C}$.

Samples of the planktonic alga Phaeocystis pouchetii were collected on $18,21,24$, and 28 Dec 1984 during the bloom of this alga in McMurdo Sound. Five stations were positioned along a roughly north-south transect that extended from the ice edge to Cape Armitage (Fig. 1). Helicopter transport was used to sample each of the 5 sites on each date. At each site, a $25 \mathrm{~cm}$ diameter hole was first drilled through the ice with a gasoline-powered Jiffy drill and then a water sample was collected from a depth of $3 \mathrm{~m}$ with a Kemmerer sampler. At the ice edge station (Stn 1) the Kemmerer sampler was lowered into open water over the ice edge. Samples were stored in Polyfoam freeze-safe containers and returned to the Eklund Biological Center at McMurdo Station. Sampling and transport took approximately $2.5 \mathrm{~h}$.

Sample analysis. Rates of carbon fixation were measured with the ${ }^{14} \mathrm{C}$ technique as described by SteemannNielsen (1952). For in situ incubations of platelet ice microalgae, samples were brought to the surface within a darkened dive hut, the interstitial water containing the microalgae was decanted, and $90 \mathrm{ml}$ aliquots of this interstitial water were inoculated with $1 \mu \mathrm{Ci}$ of $\mathrm{NaH}^{14} \mathrm{CO}_{3}$ and returned to the platelet layer by SCUBA divers for $24 \mathrm{~h}$ incubations. To terminate the incubation, divers collected the incubation bottles and the bottles were returned to the lab in a dark container on ice and filtered in less than $1 \mathrm{~h}$. In some instances,
Fig. 1. Map of McMurdo Sound showing locations of sampling sites. GH: Granite Harbor; IE: ice edge; NH: New Harbor; HP: Hut Point; CA: Cape Armitage. The roughly north-south line of dots represents the transect where samples of Phaeocystis were collected from a depth of $3 \mathrm{~m}$ from the water column beneath the ice, from Stn 1 at the ice edge to Stn $5,25 \mathrm{~km}$ distant at Cape Armitage

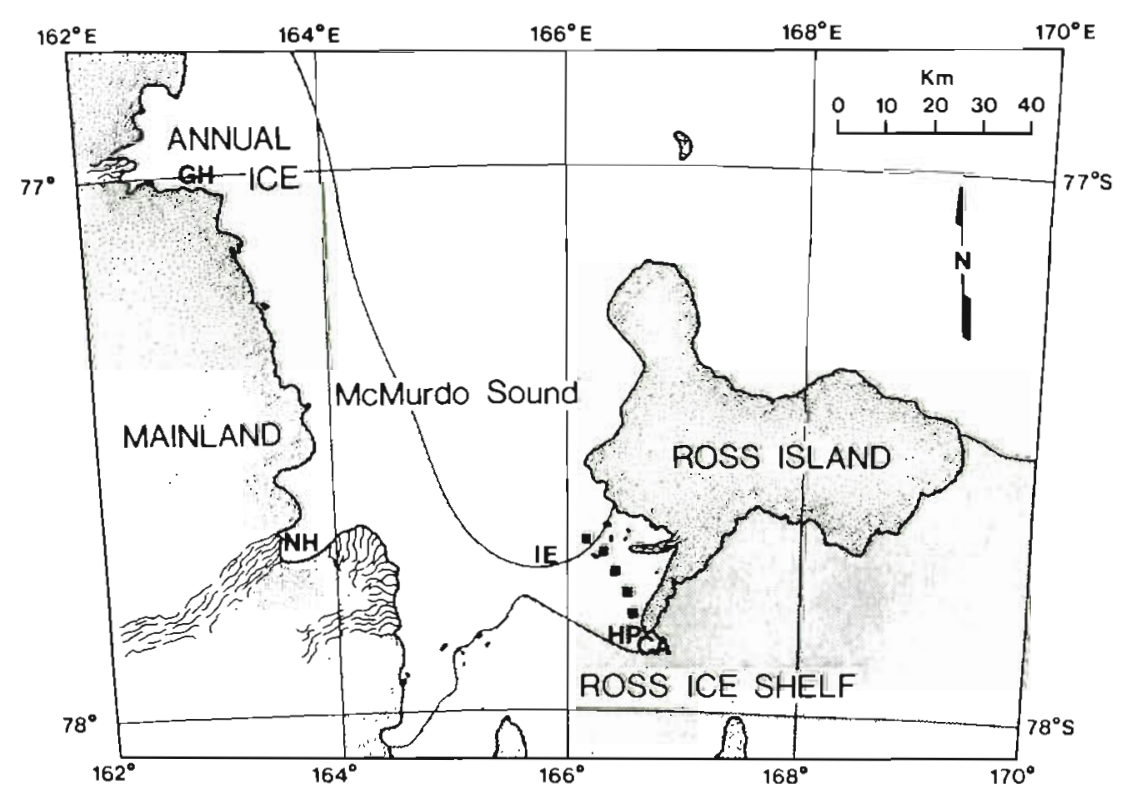


samples were returned to the laboratory where aliquots were inoculated with $\mathrm{NaH}^{14} \mathrm{CO}_{3}$ and incubated at $-2{ }^{\circ} \mathrm{C}$ for $24 \mathrm{~h}$ under artificial fluorescent light at $6 \mu \mathrm{Ein}$ $\mathrm{m}^{-2} \mathrm{~s}^{-1}$. For Phaeocystis pouchetii, photosynthesisirradiance curves were measured by the method of Lewis \& Smith (1983) as described by Palmisano et al. (1986). A $500 \mathrm{~W}$ tungsten-halogen source was used for these incubations. Samples were radioassayed using a Beckman LS100 liquid scintillation system. Seawater subsamples were taken in triplicate for measurements of carbonate alkalinity to determine total available carbon following the methods of the American Public Health Association (1971), Strickland \& Parsons (1972) and Wood (1975).

Chlorophyll $a$ and phaeopigments were extracted in $90 \%$ acetone and measured by the fluorometric technique using a Turner 111 filter fluorometer equipped with a high sensitivity door and a red-sensitive photomultiplier (Holm-Hansen et al. 1965). The fluorometer was calibrated with purified chl a (Sigma Chemical) using the spectrophotometric method and equations of Jeffrey \& Humphrey (1975) as a check on the purity of the chl a standard

Determination of in vivo absorption spectra. In vivo absorption spectra were determined by methods previously described by Kiefer \& SooHoo (1982) and Mitchell \& Kiefer (1984). Samples were collected on glassfiber filters (Whatman GF/C). First, 2 blank filters moistened with filtered seawater were placed in a lucite holder designed to position each filter in line with either the sample or reference beam of a Perkin-Elmer 571 double beam spectrophotometer. The filters were scanned between 400 and $700 \mathrm{~nm}$, and this baseline was stored in the instrument's microprocessor. The blank filter in the sample beam was then replaced with a filter containing the algal sample and this sample was scanned over the same wavelength range. The optical density at $750 \mathrm{~nm}$ was also recorded as a blank. The analog signal from the spectrophotometer was first amplified and then digitized and stored on an Osborne 1 computer equipped with a 16-channel, 8-bit analog-to-digital converter (Small Systems Designs Inc.). The stored data were then averaged, smoothed and processed as described by Kiefer \& SooHoo (1982) and Mitchell \& Kiefer (1984) to derive the specific spectral absorption coefficient, ${ }^{\circ} \mathrm{a}_{(\hat{\wedge})}$, in units of $\mathrm{m}^{2}$ $(\mathrm{mg} \mathrm{chl} \mathrm{a})^{-1}$

Irradiance measurements. Spectral downwelling irradiance and total photosynthetically available radiation (PAR) were measured at the sea ice surface, under the approximately $2 \mathrm{~m}$ of congelation ice, and under approximately $0.5 \mathrm{~m}$ of platelet ice. The spectral composition of downwelling irradiance was measured with a Biospherical Instruments MER 1000 spectroradiometer. Spectral bands were centered at 410,441,488, 507 ,
$520,540,570,589,625,656,671$, and $694 \mathrm{~nm}$, and a PAR channel was also included. The silicon photodiodes have half-band widths of $5 \mathrm{~nm}$. The spectroradiometer was deployed in 2 ways. At remote study sites and on some occasions at the Cape Armitage study site, SCUBA divers operated the instrument, making measurements under the platelet layer; or by pushing the spectroradiometer through the fragile platelet ice against the hard congelation ice, measured the spectral irradiance transmitted by the congelation ice layer alone. Patterns in under-ice spectral irradiance were monitored throughout the season at the Cape Armitage study site. Diurnal measurements of spectral irradiance were made on 16-17 Sep, 5-6 Oct, 25-26 Oct, 11-12 Nov, 23-24 Nov, 3-4 Dec, and 15-16 Dec 1984. On each occasion, the spectrum of incoming solar irradiance was measured just prior to deploying the spectroradiometer under the ice. On these dates, the spectroradiometer was programmed to take measurements every 20 min over a $24 \mathrm{~h}$ period and was attached to a mooring frozen into the ice which held the instrument in position just under the congelation ice. The digital output signal of the spectroradiometer was recorded with a DEC Professional 350 microcomputer, processed, and stored on floppy discs. Total incident PAR was recorded continuously at Cape Armitage with a Biospherical Instruments model QSR240 Solar Reference Hemispherical Irradiance Sensor coupled to a model QSR250 Digital Integrator. On 11-12 Nov, 23-24 Nov, 3-4 Dec, and 15-16 Dec, a Biospherical Instruments model QSP-200 Profiling Scalar Irradiance Sensor was attached to an extension of the spectroradiometer mooring and positioned just beneath the platelet ice layer. On these dates, PAR beneath the platelet layer was recorded continuously during the diurnal spectroradiometer studies.

Calculation of mean specific absorption coefficient, ${ }^{\circ} \overline{\mathbf{a}}$. To calculate the in vivo ${ }^{\circ} \overline{\mathrm{a}}$, both spectral irradiance $I_{(i)}$ and the spectral specific absorption coefficient of the microalgae, ${ }^{\circ} a_{(i,)}$, must be known. Since both were measured in this study, ${ }^{-\bar{a}}\left(\mathrm{~m}^{2}(\mathrm{mg} \mathrm{chl} \mathrm{a}]^{-1}\right)$ was calculated as follows:

$$
\bar{a}=\frac{400 \int^{700 o} a_{(\lambda)} \cdot I_{(\lambda)} d \lambda}{400 \int^{700} I_{(\lambda)} \cdot d \lambda}
$$

The in vivo absorption spectrum for each sample consists of 300 values of ${ }^{a} a_{(i, j}$ while the measured irradiance is restricted to 12 discrete values centered at each of the wavelengths described above. For purposes of calculating ${ }^{\circ} \bar{a}$, we chose to complete the irradiance spectrum by linear interpolation between the measured values. Note that while ${ }^{\bar{a}}$ does not depend on the amplitude of $I_{(\lambda)}$, its value does depend on the spectral distribution of available light. The value of ${ }^{-} \bar{a}$ also 
depends on the spectrum of ${ }^{\circ} \mathrm{a}_{(\lambda)}$, and therefore the photoadaptive state and pigment composition of the algae (Falkowski et al. 1985, Dubinsky et al. 1986).

Calculations of photosynthetic quantum yield, $\Phi$. The photosynthetic quantum yield was calculated in one of several ways, depending on the measurements available for each experiment.

For the alga Phaeocystis pouchetii, $\Phi$ was calculated according to Eqn (6) of Tilzer (1985), relating the slope of the light-limited portion of the photosynthesisirradiance curve $(\alpha)$ to the quantum yield and mean absorption coefficient:

$$
\Phi=\frac{\alpha}{43.2 \cdot 0^{-}}
$$

This expression converts $\alpha$, the chl $a$-specific rate of photosynthesis per available mole of quanta, to $\Phi$, the chl a-specific yield of carbon per absorbed mole of quanta. Values of $\alpha$ were determined as described by Palmisano et al. (1986). The factor 43.2 is a proportionality constant for conversion of units to mol C (Ein absorbed) $^{-1}$.

For the sea ice microalgae and the in situ incubation of Phaeocystis pouchetii, Eqn (4) of Bannister \& Weidemann (1984) was used:

$$
\Phi=\frac{\mathrm{p}^{\mathrm{B}}}{43.2 \cdot{ }^{\circ} \overline{\mathrm{a}} \cdot \mathrm{I}_{(\mathrm{PAR})}}
$$

$\mathrm{P}^{\mathrm{B}}$ is the chl a-specific rate of photosynthesis and was determined by incubation of samples at $6 \mu$ Ein $\mathrm{m}^{-2} \mathrm{~s}^{-1}$ in an incubator, a value at which photosynthesis of Antarctic sea ice microalgae is light-limited (Palmisano et al. 1985). $I_{\text {(PAR) }}$ represents the measured photosynthetically available irradiance of the incubator, and ${ }^{\circ} \bar{a}$ for each sample was determined with the absorption spectrum for that sample and the spectral irradiance for the incubator.

In the experiments where platelet ice microalgae and Phaeocystis pouchetii were incubated in situ, ${ }^{\circ} \vec{a}$ was determined with the appropriate measured under-ice irradiance spectrum and $\mathrm{I}_{(\mathrm{PAR})}$ in the above equation represents total PAR for that spectrum.

\section{RESULTS}

We have observed a consistent difference between the absorption spectra for congelation and platelet ice microalgae. In vivo absorption spectra for platelet and congelation ice algal samples collected from Cape Armitage on 3 Dec 1984 are shown in Fig. 2A. The difference spectrum of these 2 samples is shown in Fig. 2B. Absorption in the blue-green region of the spectrum of the platelet ice microalgae sample is enhanced relative to that for the congelation ice microalgae.
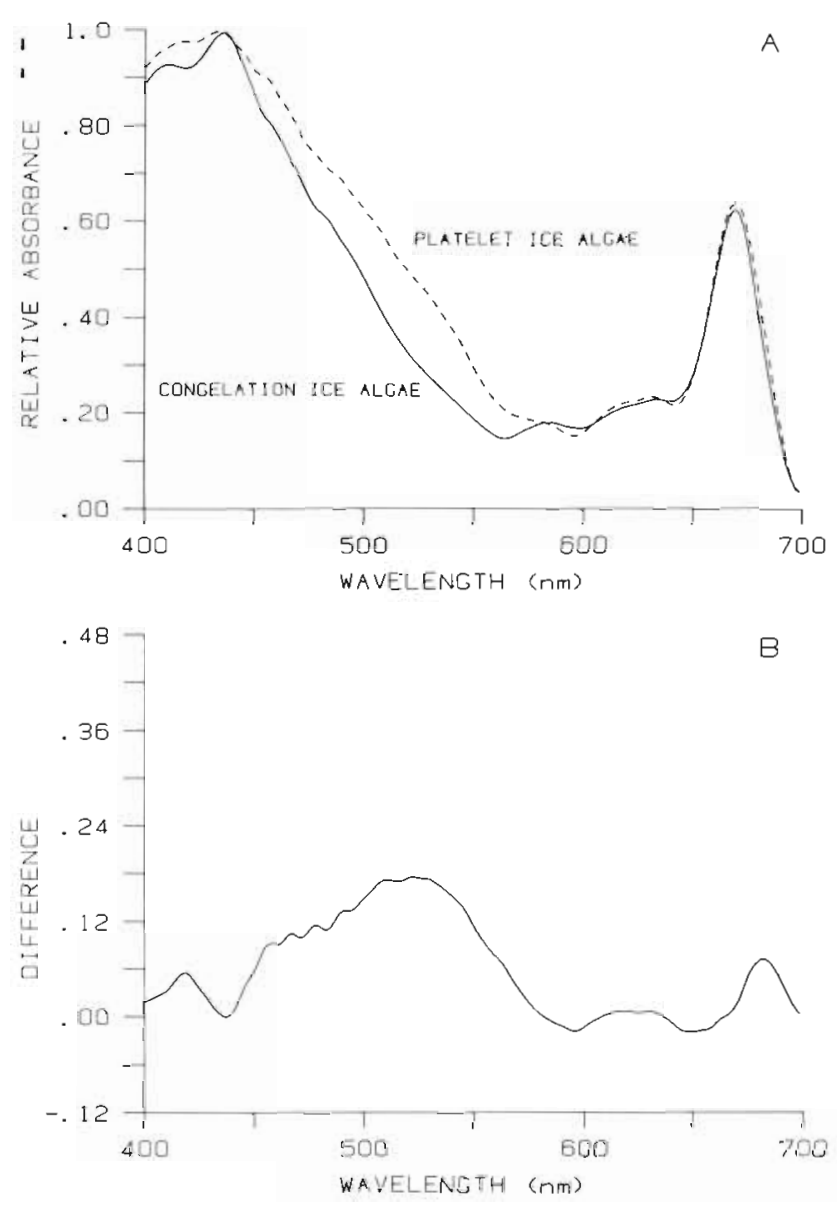

Fig. 2. (A) In vivo absorption spectra of algal assemblages from the congelation ice and from platelet ice. (B) Difference spectrum (platelet - congelation) of samples shown in (A)

The in vivo absorption spectra of Phaeocystis pouchetii samples taken from open water at Stn 1 at the ice edge on $18 \mathrm{Dec} 1984$ and from the water column under the ice at Stn 5, $25 \mathrm{~km}$ distant, at Cape Armitage on 18 Dec 1984 are shown in Fig. 3A. Their difference spectrum (Fig. 3B) demonstrates that at the beginning of the bloom, $P$, pouchetii from beneath the ice exhibits enhanced absorption of light in the blue-green region of the spectrum relative to a $P$. pouchetii sample taken from the open water at the ice edge.

Interactions of spectral irradiance, the physical environment of the ice, and absorption characteristics of the ice microalgae are summarized in Fig. 4. Spectral irradiance measurements were collected at a site near the ice edge on 12 Dec 1984. The absorption spectra for congelation and platelet ice microalgae are from samples collected at this site on the same day, and are included to help explain how each irradiance spectrum is affected by the algal 'filter' above.

Irradiance incident on the surface of the congelation ice has a relatively flat spectral distribution in the 

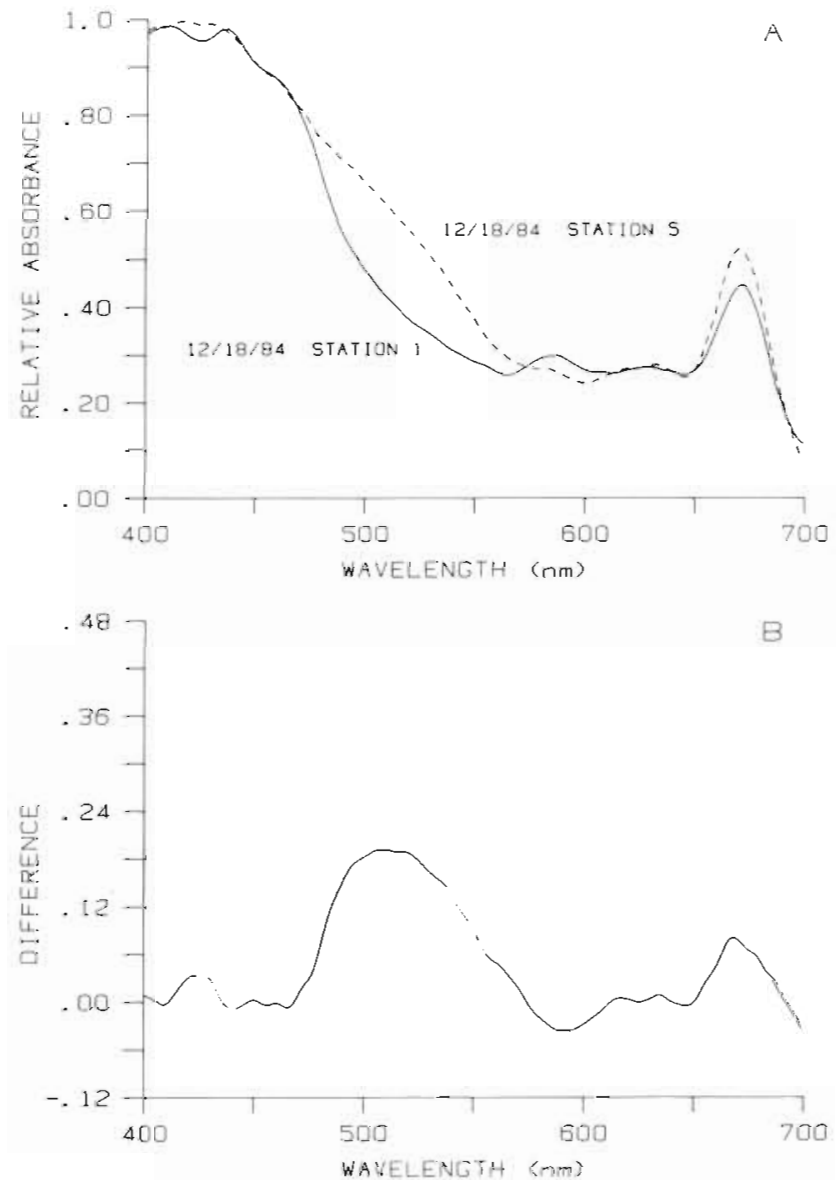

Fig. 3. (A) In vivo absorption spectra of Phaeocystis pouchetii samples taken from open water at Stn 1 at the ice edge and from the water column under the ice at Stn 5 near Cape Armitage on 18 Dec 1984. (B) Difference spectrum (Stn 5 Stn 1) of samples shown in (A)

visible (Fig. 4A), Total incident PAR at $1351 \mathrm{~h}$ on 12 Dec 1984 was $1364 \mu$ Ein $\mathrm{m}^{-2} \mathrm{~s}^{-1}$. After the effects of albedo and combined absorption by surface snow and first-year ice have been taken into account, the spectral distribution of the light is altered, and red light is attenuated rapidly. By assuming a conservative albedo of $65 \%$ and by using the spectral transmittance values for first-year white ice published by Maykut \& Grenfell (1975), the spectral properties of light incident on top of the algal layer contained in the bottom $20 \mathrm{~cm}$ of the congelation ice were estimated (Fig. 4B).

The results compare favorably with patterns of spectral irradiance measured during the 1982-1983 austral spring under $2.25 \mathrm{~m}$ of congelation ice similar in snow cover and free of microalgae reported by Palmisano et al. (1987a). Total PAR is about $46 \mu$ Ein $\mathrm{m}^{-2} \mathrm{~s}^{-1}$ or $3 \%$ of the value of PAR incident at the surface. The quanta are concentrated between 480 and $550 \mathrm{~nm}$. The absorption spectrum for congelation ice microalgae is shown in Fig. 4C. Blue and red light are selectively absorbed by the photosynthetic pigments, further narrowing the spectrum of the remaining light. After passing through the bottom portion of the congelation ice, available quanta are reduced to $1.5 \mu$ Ein $\mathrm{m}^{-2} \mathrm{~s}^{-1}$, about $0.1 \%$ of incident surface irradiance, and are concentrated in a band from 540 to $620 \mathrm{~nm}$ (Fig. 4D) wavelengths where algal absorption is minimal. Relative to congelation ice microalgae, the microalgae of the platelet layer beneath it exhibit enhanced absorption in the blue-green region of the spectrum between 500 and $550 \mathrm{~nm}$ (Fig. 4E, see also Fig. 2A). This corresponds to the absorption region of the major carotenoid accessory pigment of diatoms, the xanthophyll fucoxanthin. As a result, the irradiance spectrum measured beneath the platelet ice layer is noticeably modified by the absorption of light by fucoxanthin and other accessory pigments. Less than $1 \mu$ Ein $\mathrm{m}^{-2} \mathrm{~s}^{-1} \mathrm{PAR}$ $(0.05 \%$ of incident surface PAR $)$ is available at the top of the underlying water column for phytoplankton photosynthesis (Fig. 4F), and most of this small amount of PAR is in the green region of the spectrum where microalgae do not absorb light effectively.

Early in the season, before the development of the spring ice microalgal bloom in the congelation and platelet ice, the spectral irradiance measured under the platelet ice (Fig. 5A) more closely resembles the spectrum of solar irradiance attenuated by snow and ice alone (compare to Fig. 4B). Later in the season, the effect of the enhanced blue-green absorption of platelet ice microalgae relative to that of congelation ice microalgae is reflected by a depression in irradiance in the region of the spectrum corresponding to the band of fucoxanthin absorption, about 500 to $540 \mathrm{~nm}$ (Fig. $5 B)$. The magnitude of this effect on the under-ice spectral irradiance depends on the presence or absence of a platelet ice layer, the degree of colonization of this layer by ice microalgae when such a läyer is present. and also the photoadaptive state of the microalgal pigment systems. At our major study site at Cape Armitage, no platelet layer was present during the 1980 and 1981 field seasons. During the 1982, 1983, and 1984 field seasons, a 0.25 to $1.0 \mathrm{~m}$ platelet layer was present at this site. The under-ice irradiance spectra in Fig. 5 are representative of the extremes measured since 1982 (Sullivan et al. 1983, Sullivan et al. 1984, Palmisano et al. 1987a), and as such, characterize the within-season and between-season variability in spectral irradiance available to the phytoplankton under the seasonal fast ice of McMurdo Sound.

The values of mean absorption coefficient, ${ }^{\circ} \bar{a}$, for samples of phytoplankton dominated by the prymnesiophyte Phaeocystis pouchetii are shown in Fig. 6. Two patterns are evident. First, on all sampling dates, ${ }^{\circ} \bar{a}$ was greatest for open water samples from Stn 1 at the ice edge and decreased for samples taken from the water 


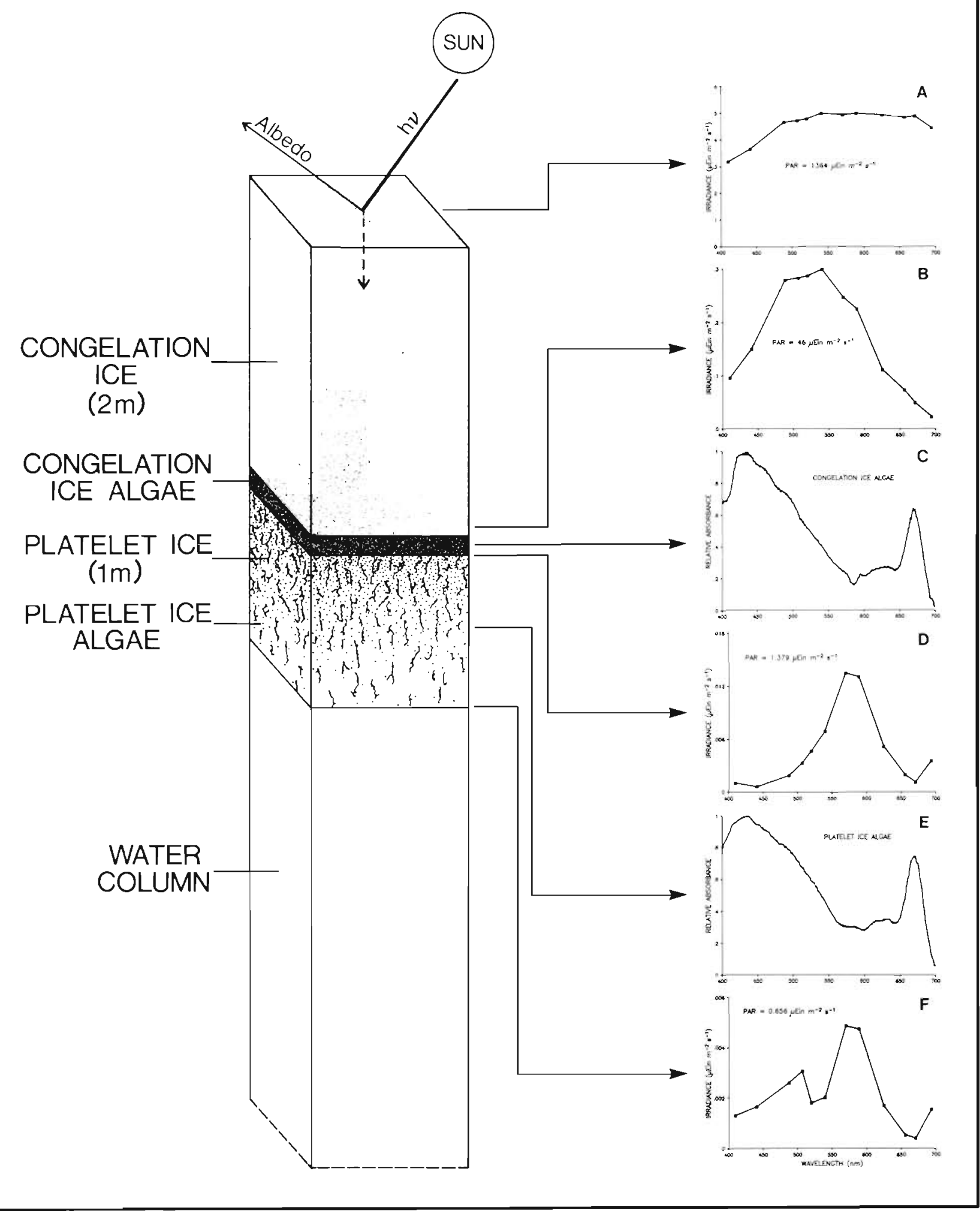

Fig. 4. Diagram showing spectral characteristics of irradiance at different 'depths' within the ice structure and in vivo spectral absorption characteristics of the 2 ice microalgal assemblages. (A) Spectral irradiance incident on surface of ice. PAR $=1364 \mu$ Ein $\mathrm{m}^{-2} \mathrm{~s}^{-1}$. (B) Resulting irradiance spectrum after a $65 \%$ loss to albedo and after passing through $1.8 \mathrm{~m}$ of first-year sea ice. PAR $=$ $46 \mu$ Ein $\mathrm{m}^{-2} \mathrm{~s}^{-1}$. (C) In vivo absorption spectrum of ice microalgae from bottom $0.2 \mathrm{~m}$ of congelation ice. (D) Spectral irradiance measured just under the congelation ice. PAR $=1.379 \mu$ Ein $\mathrm{m}^{-2} \mathrm{~s}^{-1}$ (E) In vivo absorption spectrum of microalgae from the platelet ice layer. (F) Spectral irradiance measured just beneath the platelet ice layer. PAR $=0.656 \mu$ Ein $\mathrm{m}^{-2} \mathrm{~s}^{-1}$ 


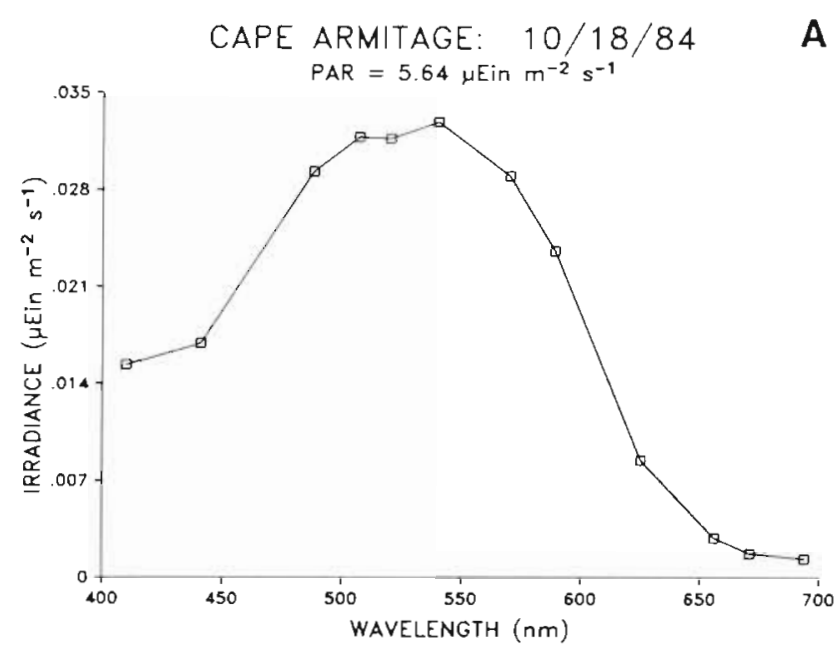

ICE EDGE: $12 / 12 / 84$

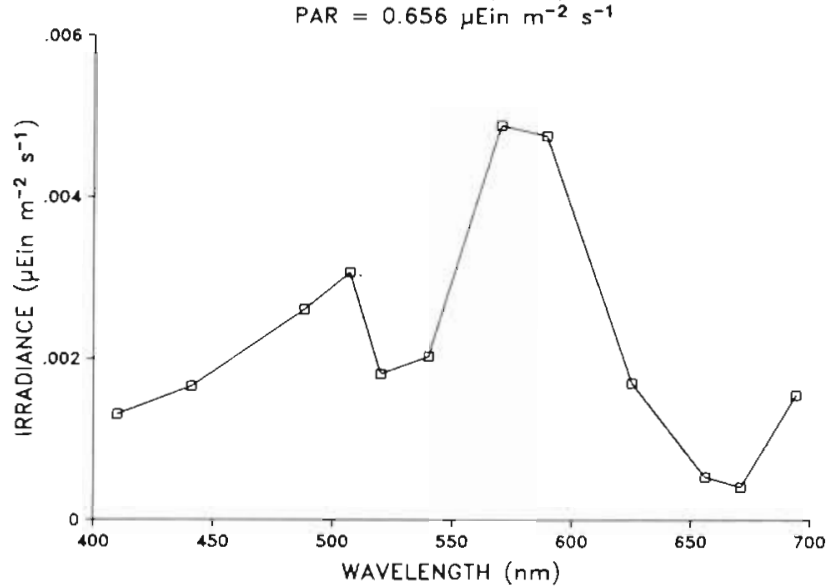

Fig. 5. (A) Spectral irradiance measured under approximately $2 \mathrm{~m}$ of sea ice and a $1 \mathrm{~m}$ platelet layer at Hut Point on $18 \mathrm{Oct}$ 1984. (B) Spectral irradiance measured under approximately $2 \mathrm{~m}$ of sea ice and a $1 \mathrm{~m}$ platelet layer at the ice edge on 12 Dec 1984

column under the seasonal ice, leveling off to about $0.008 \mathrm{~m}^{2}(\mathrm{mg} \mathrm{chl} \mathrm{a})^{-1}$ at Stns 4 and 5. Second, at the ice edge (Stn 1), values of ${ }^{\circ} \overline{\mathrm{a}}$ decreased over time from 0.029 to $0.018 \mathrm{~m}^{2}$ (mg chl a) ${ }^{-1}$ as the bloom progressed.

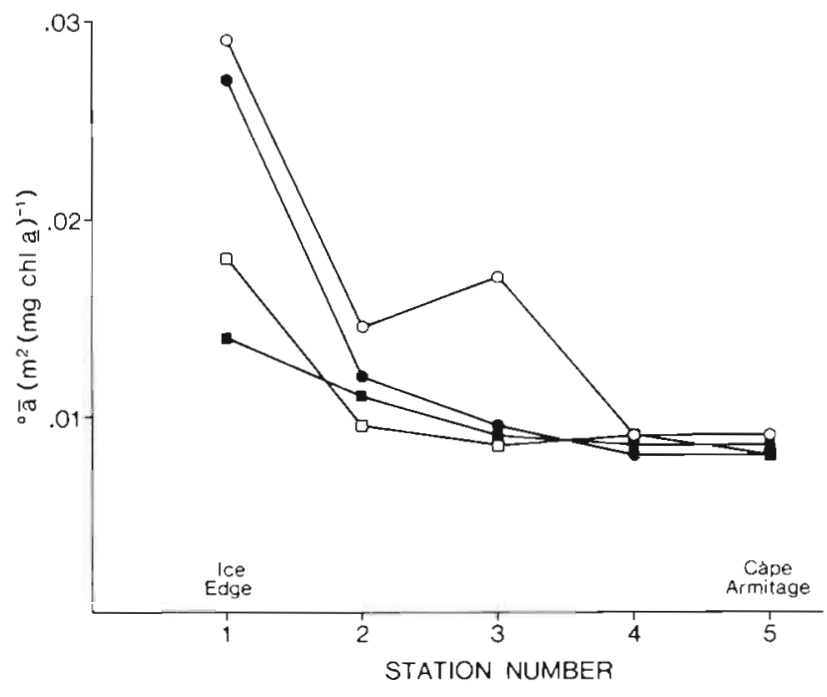

Fig. 6. Values of the mean spectral absorption coefficient, ${ }^{\circ} \bar{a}$ for Phaeocystis-dominated plankton samples collected at each station of the transect on each date of sampling: (ㅇ) $18 \mathrm{Dec}_{i}$ (•) $21 \mathrm{Dec}$; (ㅁ) $24 \mathrm{Dec}_{\text {; }}(\bullet) 28 \mathrm{Dec}$

The values of $\bar{a}$ and quantum yield for congelation and platelet ice microalgae are reported in Table 1. Included are both ${ }^{\circ} \overline{\mathrm{a}}_{(\text {in situ }),}$, the mean specific absorption coefficient determined using the measured in situ irradiance, and ${ }^{\circ} \overline{\mathrm{a}}_{\text {(apparent) }}$, the mean specific absorption coefficient calculated with the spectral irradiance of the incubator fluorescent source. Values of the same parameters measured on 24 and 28 Dec 1984 for Phaeocystis pouchetii are listed in Table 2. Quantum yields for $P$. pouchetii included are for the ice edge station. On the other dates, the great difference between the under-ice spectral irradiance (see Fig. 4D, F) and the spectral irradiance of the incubator made determination of $\Phi$ subject to error (see Lewis et al. 1985a, b for discussion). For the ice edge stations, the in situ spectral irradiance is closer to the spectral irradiance of the incubator source, and only a small difference between $\overline{\mathrm{a}}_{(\mathrm{in} \text { situ) }}$ and ${ }^{\mathrm{o}} \overline{\mathrm{a}}_{\text {(apparent) }}$ results.

Table 1. Measured values of $\Phi_{m}$ and ${ }^{\circ} \bar{a}$ for congelation and platelet ice microalgae

\begin{tabular}{|c|c|c|c|c|c|c|}
\hline Sample site & $\begin{array}{c}\text { Sample date } \\
(1984)\end{array}$ & Sample type & $p^{81}$ & ${ }^{\circ} \bar{a}^{2}$ in situ & $o^{-2}$ apparent & $\Phi_{\mathrm{m}}{ }^{3}$ \\
\hline Ice edge & $12 \mathrm{Dec}$ & Congelation & 0.0392 & 0.00675 & 0.010 & 0.013 \\
\hline New Harbor & $13 \mathrm{Dec}$ & Congelation & 0.0504 & 0.00727 & 0.012 & 0.014 \\
\hline Granite Harbor & $13 \mathrm{Dec}$ & Congelation & 0.0490 & 0.00625 & 0.010 & 0.016 \\
\hline Hut Point & $17 \mathrm{Dec}$ & Congelation & 0.0796 & 0.00576 & 0.009 & 0.029 \\
\hline Cape Armitage & $3 \mathrm{Dec}$ & Platelet & 0.0181 & 0.00580 & - & 0.041 \\
\hline Tent Island & $9 \mathrm{Dec}$ & Platelet & 0.0600 & 0.0089 & 0.011 & 0.018 \\
\hline Ice edge & $12 \mathrm{Dec}$ & Platelet & 0.1010 & 0.0097 & 0.010 & 0.033 \\
\hline
\end{tabular}


Table 2. Values of $\alpha,{ }^{-} \bar{a}$, and $\Phi_{m}$ for the prymnesiophyte Phaeocystis pouchetii. Data for $\alpha$ are taken from Palmisano et al. (1986)

\begin{tabular}{|c|c|c|c|c|}
\hline Date & Stn & $\alpha^{1}$ & $\mathrm{o}^{2}{ }^{2}$ & $\Phi_{m^{3}}^{3}$ \\
\hline 24 Dec 1984 & 1 & 0.0245 & 0.018 & $0.032^{4}$ \\
\hline 28 Dec 1984 & 1 & 0.0425 & 0.015 & $0.054^{4}$ \\
\hline $3 \mathrm{Jan} 1985^{5}$ & 5 & 0.057 & 0.020 & $0.028^{6}$ \\
\hline \multicolumn{5}{|c|}{$\begin{array}{l}{ }_{1}^{1} \text { Units are } \mathrm{mg} \mathrm{C}(\mathrm{mg} \mathrm{chl} a)^{-1} \mathrm{~h}^{-1}\left(\mu \text { Ein } \mathrm{m}^{-2} \mathrm{~s}^{-1}\right)^{-1} \\
\left.{ }^{2} \text { Units are } \mathrm{m}^{2} \text { (mg chl a) }\right)^{-1} \\
\left.{ }^{3} \text { Units are mol } \mathrm{C} \text { (Ein absorbed) }\right)^{-1} \\
{ }^{4} \text { Calculated according to Eqn (2) } \\
{ }^{5} \text { Incubated in situ for } 24 \mathrm{~h} \\
{ }^{6} \text { Calculated according to Eqn (3) }\end{array}$} \\
\hline
\end{tabular}

\section{DISCUSSION}

Spectral absorption of light by sea ice microalgae and phytoplankton

The vertical component of the sea ice environment is highly heterogeneous with respect to light. Within the approximately 2 to $3 \mathrm{~m}$ vertical distance from the airsnow or air-ice interface to the ice-water interface at the bottom of the platelet layer, a range of spectral variability usually observable only by examining several oceans or water types is found. Because the attenuation coefficients of snow and sea ice are 10 to 100 times greater than typical values for water (Thomas 1963, Maykut \& Grenfell 1975, Grenfell \& Maykut 1977), and because large crops of sea ice microalgae are concentrated within a small layer (about $20 \mathrm{~cm}$ or less in congelation ice and about $1 \mathrm{~m}$ or less in platelet ice) relative to phytoplankton in the water column, the changes in both total PAR and spectral irradiance that occur over tens of meters in an open water column are compressed to within a vertical distance of only 2 to $3 \mathrm{~m}$ in the sea ice environment.

Most of the solar irradiance incident on the surface of the snow and ice is reflected back into the atmosphere. The term albedo is used to describe the ratio of reflected irradiance to incident irradiance (Grenfell \& Perovich 1984). Variations in the albedo of ice are due to snow cover, vapor bubble density, crystal structure, and free water content of the upper layers (Grenfell \& Perovich 1984). For snow, the albedo for polychromatic light may vary from 60 to $81 \%$ (Thomas 1963). Grenfell \& Maykut (1977) report values at $500 \mathrm{~nm}$ from $25 \%$ over Arctic melt ponds to $93 \%$ over dense, dry, Arctic snow. Grenfell \& Perovich (1984) report values for spectrally-integrated ( 400 to $2400 \mathrm{~nm}$ ) albedo that vary from $21 \%$ for melt ponds to $43 \%$ for bare ice to $77 \%$ for snow. Roulet \& Adams (1986) reported an average value of albedo for the snow cover of a freshwater subarctic lake of approximately $74 \%$. Measurements of albedo for PAR in 1982 for snow-covered first-year white ice of McMurdo Sound were $91.8 \%$ (Palmisano et al. 1987 a). The remaining irradiance is attenuated rapidly in passing through the upper $1.8 \mathrm{~m}$ of snow and sea ice. The congelation ice microalgae, concentrated in the bottom $20 \mathrm{~cm}$ of the congelation ice, have available a spectrum with quanta concentrated between 450 and $580 \mathrm{~nm}$ (Fig. 4B). While not identical, this spectrum is similar to those at depth (14 to $100 \mathrm{~m}$ ) for the blue waters of the Sargasso Sea reported by Morel (1978). A significant proportion of quanta are available in the blue and blue-green regions of the spectrum where they can be absorbed by photosynthetic pigments. Using absorption spectra for samples from each layer and spectra of irradiance available to the 3 algal assemblages considered here, PUR for each layer of microalgae can be calculated (Morel 1978). PUR for the congelation ice microalgae is $57 \pm 7 \%(N=5)$ of their PAR. After passing through an additional distance of only $20 \mathrm{~cm}$, the spectrum available to the underlying platelet ice microalgae is very different (Fig. 4D). In this visibly-narrowed spectrum, PAR is concentrated between about 540 and $620 \mathrm{~nm}$, where photosynthetic pigments absorb minimally, and the spectral irradiance resembles that for green waters at depth described by Morel (1978). Consequently, the spectrum of irradiance available to the platelet ice microalgae contains $31 \pm$ $2 \%(\mathrm{~N}=6)$ of PAR as PUR. The enhanced ability of platelet ice microalgae to absorb blue-green light (Fig. $2 \mathrm{~A} \& 4 \mathrm{E}$ ) results in an irradiance spectrum which has been altered further and which contains even less PUR for phytoplankton at the top of the water column. Even though the phytoplankton present at this time of the season may have increased absorption in the bluegreen region of the spectrum as did Phaeocystis pouchetii at the beginning of our study (Fig. 3A), little blue-green light is available to be absorbed. As a consequence, PUR is only $25 \pm 2 \%(N=6)$ of PAR.

Morel (1978), expressing PAR and PUR at depth as functions of PAR and PUR at the surface, demonstrated that at the depth in the water column where available energy is reduced to $1 \%$ of its surface value, PUR can vary in a ratio of about $3: 1$ depending on the optical water types. When our data are expressed as a function of PAR and PUR for the congelation ice microalgae (our nominal 'surface'), data for the platelet ice microalgae and phytoplankton coincide with Morel's data (Morel 1978; his Fig. 8) for the green productive waters of the Mauritanian upwelling system (Table 3). The PUR for platelet ice microalgae is $1.6 \%$ of that for the congelation ice microalgae, and for the phytoplankton at the top of the water column under the seasonal fast ice PUR is only $1.0 \%$ of that for the congelation ice microalgae (Table 3) 
Table 3. PAR and PUR for each layer of microalgae expressed both in $\mu$ Ein $\mathrm{m}^{-2} \mathrm{~s}^{-1}$ and as a percentage of the corresponding value at the surface of the congelation ice algal layer. Data are from measurements and samples taken at a station near the ice edge on 12 Dec 1984

\begin{tabular}{|lcccc|}
\hline Layer & $\operatorname{PAR}_{(Z)}$ & $\mathrm{PUR}_{(Z)}$ & $\mathrm{PAR}_{(\mathrm{z})} / \mathrm{PAR}_{(0)}$ & $\begin{array}{c}\mathrm{PUR}_{(\mathrm{z})} / \mathrm{PUR}_{(0)} \\
\%\end{array}$ \\
\hline Congelation ice algae & 46 & 26 & 100 & 100 \\
Platelet ice algae & 1.38 & 0.42 & 3 & 1.6 \\
Phytoplankton & 0.66 & 0.26 & 1.4 & 1.0 \\
\hline
\end{tabular}

From observations of patterns of primary production and spectral irradiance in a variety of water types, Morel (1978) concluded that in deep layers of productive water, actual light absorption per unit chl a must be appreciably higher than would be indicated by assumption of constant absorption properties throughout the water column, particularly in the blue-green to green region of the spectrum. Independent experimental observations support Morel's conclusion. Neori et al. (1984) reported systematic changes in absorption with depth and vertical stability of the water column. In samples from deeper waters, in vivo absorption spectra showed enhanced blue-green absorption. Since similar patterns were inducible by incubating seawater samples at different irradiances, the authors attributed their observations to photoadaptation rather than vertical changes in algal taxa and associated pigment groups. SooHoo et al. (1986) observed enhanced blue-green absorption in response to reduced growth irradiance in cultures of diatoms, dinoflagellates, chlorophytes and chrysophytes. As reported here (Fig. 2A), and by Sullivan et al. (1984), platelet ice microalgae, which can be thought of as analogous to 'deep' phytoplankton in productive waters, exhibit enhanced blue-green absorption relative to congelation ice microalgae. These observations are consistent with well-documented changes in the organization and concentrations of photosynthetic pigments of marine microalgae in response to light adaptation (Perry et al. 1981, Prezelin 1981, Richardson et al. 1983), and suggest an increased role of the diatom pigment fucoxanthin in gathering light energy for photosynthesis in the predominantly blue-green irradiance environment of the sea ice. The light harvesting ability per unit chl a of algae adapted to low growth irradiance may be decreased due to self-shading of thylakoids within and between chloroplasts as documented and discussed by Dubinsky et al. (1986). Since fucoxanthin may transfer absorbed energy to chl a with efficiencies of up to $100 \%$ (see review by Siefermann-Harms 1985), increased light absorption by fucoxanthin in the bluegreen region of the spectrum may make a major contribution of absorbed quanta to the photosynthetic reaction centers.
This photoadaptive pattern appears to be in response to low photon flux density rather than chromatic adaptation in response to the changing spectral quality of the irradiance. SooHoo et al. (1986) induced the response in cultures by reducing the irradiance without changing the spectral quality. Neori et al. (1984) were able to produce enhanced blue-green absorption in samples of natural phytoplankton shaded with neutral screening on the deck of a ship. These observations are consistent with the conclusions reached in the review by Richardson et al. (1983) that while light quality may be important in controlling some metabolic processes in phytoplankton, photon flux density plays a more important role than light quality in the control of microalgal distributions and survival of microalgae.

With the data in hand, we can quantify the advantage conferred on platelet ice microalgae by this increased blue-green absorption. As discussed in a preceding paragraph, approximately 29 to $33 \%$ of PAR for platelet ice microalgae is photosynthetically usable. With the same irradiance spectrum available to them an algal assemblage without increased blue-green absorption (like the congelation ice microalgae spectrum in Fig. 2A) would have only 23 to $27 \%$ of PAR as PUR. Increased blue-green absorption enables the platelet ice microalgae to harvest an extra 2 to $10 \%$ PUR.

\section{Mean specific absorption coefficients and quantum yield}

The values of ${ }^{\circ} \bar{a}$ for sea ice microalgae (Tabie 1 ) and Phaeocystis pouchetii (Table 2) are consistent with patterns observed by Atlas \& Bannister (1980) and Morel (1978) for microalgae in green productive waters. Atlas \& Bannister (1980) observed that ${ }^{\circ} \mathrm{a}$ decreased from $0.012 \mathrm{~m}^{2}(\mathrm{mg} \mathrm{chl} a)^{-1}$ near the surface to about $0.005 \mathrm{~m}^{2}(\mathrm{mg} \mathrm{chl} \mathrm{a})^{-1}$ at the $0.1 \%$ light penetration depth in green waters. Morel (1978) reported that in green waters, the value of this coefficient decreases by 20 or $30 \%$, relative to the surface value, with depth. In spite of the large difference in PAR incident on the layer of congelation ice microalgae and that incident on the platelet ice layer (Fig. 4), we 
observed no significant difference in ${ }^{\circ} \overline{\mathrm{a}}$ for these 2 ice algal assemblages. Remember that while the value of ${ }^{-} \bar{a}$ does not depend on the magnitude of irradiance available, it does depend on both the spectral distribution of that irradiance and on the pigment composition of the algae as reflected in the in vivo absorption spectra. The high standing stock of congelation ice

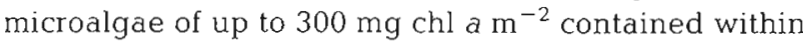
a $20 \mathrm{~cm}$ layer, but usually concentrated within the bottom 3 to $5 \mathrm{~cm}$ of that layer, alters the irradiance spectrum rapidly as light is selectively absorbed. Consequently, only those microalgae on the upper surface of this layer have available to them an irradiance spectrum like that shown in Fig. $4 \mathrm{~B}$. Most of the congelation ice microalgae are exposed to a spectrum of predominantly blue-green to green light. For $P$. pouchetii, the open water environment of Stn 1 probably underwent a transition from blue toward green, undergoing not only a reduction in total PAR but also spectral alteration as the $P$. pouchetii bloom progressed and chl a concentration in the water column at the ice edge increased from 2.5 to $12 \mu \mathrm{g} \mathrm{l}^{-1}$ between 18 and $24 \mathrm{Dec}$ 1984

The thickness of the platelet layer under an experimental quadrat with no snow cover at Cape Armitage was observed by divers to remain at about $0.5 \mathrm{~m}$ from September through mid-December 1984. By 19 Dec, the platelet layer had decreased to only $0.3 \mathrm{~m}$. Ablation of platelets, which usually begins in the third or fourth week of December, and subsequent loss of the platelet ice algal layer, would affect PAR for phytoplankton photosynthesis, and the broadened spectrum in the absence of selective absorption by platelet ice microalgae should result in an increased value of ${ }^{\circ} \bar{a}$. The timing of the onset of the Phaeocystis pouchetii bloom in the open waters of the Ross Sea, its subsequent movement under the sea ice of McMurdo Sound, and the ablation of the platelet ice layer could have an effect on the duration and magnitude of the $P$. pouchetii bloom under the ice and consequently, the contribution of the $P$. pouchetii carbon to the total carbon budget of McMurdo Sound.

Bannister \& Weidemann (1984) reviewed the literature on quantum yield and discussed implications of methodological problems associated with estimating $\Phi$ on reported values. Certain generalizations about the behaviour of $\Phi$ may be stated. First, $\Phi$ increases with increasing depth and decreasing growth irradiance in the water column, and usually reaches a maximum constant value, usually denoted $\Phi_{m}$, at irradiances that are less than saturating to photosynthesis (Tyler 1975, Dubinsky \& Berman 1976, Morel 1978, Kishino et al. 1986). Second, values of $\Phi$ from near the bottom of the euphotic zone may approach the theoretical maximum quantum yield of $0.10 \mathrm{~mol} \mathrm{O}_{2}$ (Ein absorbed) $^{-1}$ or 0.06 to $0.08 \mathrm{~mol} \mathrm{C}$ (Ein absorbed $)^{-1}$ (Bannister \& Weidemann 1984). Third, $\Phi$ might be affected by the nutrient supply of microalgae, although experimental evidence to date is based on batch cultures of microalgae and therefore may not pertain to in situ growth (Kok 1948, Morel 1978. Welschmeyer \& Lorenzen 1981). Finally, Jacques (1983), Tilzer et al. (1985, 1986), and Palmisano et al. (1987b) present data suggesting that photosynthesis at subsaturating irradiance at the extremely low temperatures characteristic of polar seas may be temperature-dependent due to decreases in $\Phi_{\mathrm{m}}$.

The values of $\Phi_{\mathrm{m}}$ for congelation ice microalgae and platelet ice microalgae range from 0.013 to $0.029 \mathrm{~mol} \mathrm{C}$ (Ein absorbed) $^{-1}$ and from 0.018 to $0.041 \mathrm{~mol} \mathrm{C}$ (Ein absorbed) $^{-1}$ respectively (Table 1 ). Values of $\Phi_{m}$ for Phaeocystis pouchetii range from 0.0287 to 0.0545 mol C (Ein absorbed) ${ }^{-1}$ (Table 2). Our values for $\Phi_{m}$ may be overestimates by a factor of 10 to $30 \%$ since our spectroradiometer measured downwelling irradiance with a cosine collector rather than scalar irradiance with a spherical detector. Højerslev (1978), Morel (1978), and Bannister \& Weidemann (1984) recommend scalar irradiance measured with a spherical detector as the most appropriate measure of light available to phytoplankton. In the case of sea ice microalgae, where sea ice acts as an efficient diffuser, scalar irradiance is probably more appropriate as well. Even after taking this into consideration, the values reported here are representative of values of $\Phi_{\mathrm{m}}$ reported for microalgal photosynthesis from a wide range of locales and environments (Table 4).

We found no significant difference in $\Phi_{\mathrm{m}}$ between congelation ice microalgae and platelet ice microalgae or Phaeocystis pouchetii. In spite of their different growth irradiances (Fig. 4), these 3 assemblages are all shade-adapted, growing at in situ irradiances which are less than saturating for photosynthesis. Relative to phytoplankton distributed through the water column of open oceans, the microalgal assemblages in this study represent a narrow range of photoadapted states. The variability in the results may be due to differences in species composition or possibly the stage of development in blooms at different sites. Palmisano et al. (1985) reported evidence indicating that the congelation ice microalgae at Cape Armitage in mid-December 1983 were senescent.

Tilzer et al. $(1985,1986)$ report even lower quantum yields ranging from 0.0027 to $0.0346 \mathrm{~mol} \mathrm{C}$ (Ein absorbed) ${ }^{-1}$ for Antarctic phytoplankton from the Scotia Sea and Bransfield Strait, and a $Q_{10}$ for lightlimited photosynthesis of 2.6 for temperatures between -1.5 and $+2.6^{\circ} \mathrm{C}$. Palmisano et al. (1987b) found that assimilation number and $\alpha$ of both congelation ice microalgae and platelet ice microalgae were tempera- 
Table 4. Values of $\Phi_{\mathrm{m}}$ for microalgae reported in the literature

\begin{tabular}{|c|c|c|}
\hline Source & Location & $\Phi_{n}$ \\
\hline Tyler 1975 & $\begin{array}{l}\text { Area west of Guyaquil, Ecuador, bounded by } 2^{\circ} 56^{\prime} \text { to } \\
5^{\circ} 32^{\prime} \mathrm{S} \text { and } 84^{\circ} 50^{\prime} \text { to } 87^{\circ} 52^{\prime} \mathrm{W} \text { : bottom of euphotic zone }\end{array}$ & 0.04 \\
\hline Tyler 1975 & $\begin{array}{l}\text { Region south and southwest of Gulf of Panama } 4^{\circ} 32^{\prime} \mathrm{N} \text {, } \\
82^{\circ} 58^{\prime} \mathrm{W}, 6^{\circ} 26^{\prime} \mathrm{N}, 79^{\circ} 55^{\prime} \mathrm{W}\end{array}$ & 0.065 \\
\hline Dubinsky \& Berman 1976 & Lake Kinneret, Israel: bottom of euphotic zone & $0.03-0.07$ \\
\hline Morel 1978 & Mauritanian upwelling region: bottom of euphotic zone & $0.01-0.10$ \\
\hline Welschmeyer \& Lorenzen 1981 & $\begin{array}{l}\text { Laboratory cultures at subsaturating light, exponential } \\
\text { growth }\end{array}$ & $0.04-0.075$ \\
\hline Bannister \& Weidemann 1984 & Lake Irondequoit Bay, New York & 0.04 \\
\hline Dubinsky et al. 1984 & Lake Constance, Germany: bottom of euphotic zone & $0.051-0.06$ \\
\hline Tìlzer 1984 & Lake Constance, Germany: seasonal range at midday & $0.022-0.092$ \\
\hline Tilzer et al. 1985,1986 & South Scotia Sea and Bransfield Strait & $0.0024-0.0346$ \\
\hline Meffert \& Overbeck 1985 & Small North German lakes & $0.01-0.08$ \\
\hline Kishino et al. 1986 & Japan Sea: subsurface chl a maximum & $0.033-0.094$ \\
\hline \multirow[t]{2}{*}{ This study } & Sea ice microalgae from McMurdo Sound, Antarctica & $0.013-0.041$ \\
\hline & Phaeocystis pouchetij from McMurdo Sound, Antarctica & $0.028-0.054$ \\
\hline
\end{tabular}

ture-dependent, reaching optimal values at approximately +6 and $+2{ }^{\circ} \mathrm{C}$ respectively. Kottmeier et al (1985) measured a fairly constant in situ temperature of $-1.9^{\circ} \mathrm{C}$ within the sea ice and underlying water column in mid-December 1984. While the in situ temperatures for the microalgae in this study certainly fall within the range for the temperature effect observed by Tilzer et al. (1986), the data reported in this study do not permit us to determine if the low in situ temperature affected maximum quantum yield. The range in the values of $\Phi_{\mathrm{m}}$ reported here is no greater than that observed for $\Phi_{m}$ at temperate locales (Table 4). The values of $\alpha$ reported by Palmisano et al. (1987b) for congelation and platelet ice microalgae determined at 4 temperatures ranging from $-2{ }^{\circ} \mathrm{C}$ to $+6^{\circ} \mathrm{C}$ can be converted to $\Phi_{m}$ using Eqn (2) and assuming a value of 0.01 for ${ }^{\circ} \bar{a}$. The values derived from that study range from 0.03 to $0.08 \mathrm{~mol} \mathrm{C}$ (Ein absorbed) ${ }^{-1}$, and rather than showing a decrease with temperature, are instead somewhat higher than those reported here. Independent, carefully-controlled experiments were carried out with sea ice microalgae at McMurdo Sound in November-December 1986 to determine if the extremely low in situ temperatures experienced by sea ice microalgae affect $\alpha$, and therefore $\Phi_{m}$, in the manner suggested by Tilzer et al. $(1985,1986)$. Preliminary analysis of the results demonstrates that light-limited photosynthesis as reflected in values of $\alpha$ did decrease with decreasing temperature (Sullivan unpubl. data). The experiments reported by Palmisano et al. (1987b) were done with samples collected on 31 Oct and 1 Nov, a full month prior to the experiments described in this study. The differences between the 2 studies may reflect real differences in the physiological state of the ice microalgae at different stages of the ice algal bloom.

\section{CONCLUSIONS}

Sea ice microalgae and phytoplankton in the underlying water column live in a vertically heterogeneous light environment. Changes in total PAR and spectral irradiance comparable to those observed over tens of meters in the water column of the oceans are compressed to only a few meters in the sea ice environment. Due to rapid absorption of blue and red light by ice and photosynthetic pigments of ice microalgae, the irradiance spectrum is dominated by green light.

Sea ice microalgae and the prymnesiophyte Phaeocystis pouchetii are able to adapt to reductions in growth irradiance by increasing absorption of bluegreen light. Platelet ice microalgae consistently demonstrate enhanced blue-green absorption relative to congelation ice algae. This enables the platelet ice algae to harvest 2 to $10 \%$ more of PAR than nonadapted algae placed in the same light environment.

The quantum yield of light limited photosynthesis did not appear to reach a constant value. The range of values observed was typical for that observed in a wide variety of locales and environments, and possibly reflects differences in species composition and physiological state of the ice microalgae

Our results demonstrate that due to significant alteration in the spectral distribution of light by microalgal 
absorption and attenuation by the ice itself, broadband polychromatic light measurements are inadequate for detailed studies of photosynthesis in sea ice algae. In this green light-dominated environment, the assumption of a constant value for the mean specific absorption coefficient may be justified under certain circumstances or as a first approximation, but that value is not the popular $0.016 \mathrm{~m}^{2}$ (mg chl a) ${ }^{-1}$ (Bannister 1974) previously applied in many studies. The influences of narrowing of the under-ice irradiance spectrum to a green-dominated state and the alterations in in vivo absorption spectra of ice algae observed in this study lead us to conclude that for sea ice microalgae and phytoplankton under sea ice colonized by ice microalgae, a value of 0.008 to $0.01 \mathrm{~m}^{2}(\mathrm{mg} \mathrm{chI} \mathrm{a})^{-1}$ is more appropriate.

Acknowledgements. The authors thank the U.S. Naval Support Force in Antarctica and ITT, Antarctic Services for logistic support. Mr. John Wood and Mr. Mike Miller assisted with dives. This study was funded by National Science Foundation grants DPP 81-17237 to C. W. S., DPP 83-04985 to A. C. P. and C. W. S., and National Aeronautics and Space Administration grant NAGW-317 to J. S. H.

\section{LITERATURE CITED}

Alexander, V. (1974). Primary productivity regimes of the nearshore Beaufort Sea with reference to the potential role of ice biota. Symposium on the Beaufort Sea, Coastal and Shelf Research. Arctic Inst. North America, Arlington, Virginia, p. 609-632

American Public Health Association (1971). Standard methods for the examination of water and wastewater. 13th edn. Washington, D.C.

Atlas, D., Bannister, T T. (1980). Dependence of mean spectral extinction coefficient of phytoplankton on depth, water color and species. Limnol. Oceanogr. 25: 157-159

Bannister, T. T. (1974). Production equations in terms of chlorophyll concentration, quantum efficiency, and upper limit to production. Limnol. Oceanogr. 19: 1-12

Bannister, T. T., Weidemann, A. D. (1984). The maximum quantum efficiency of phytoplankton photosynthesis in situ. J. Plankton Res. 6: 275-294

Baumert, H., Uhlmann, D. (1983). Theory of the upper limit to phytoplankton production per unit area in natural waters. Int. Revue ges. Hydrobiol. 68: 753-783

Bunt, J. S. (1963). Diatoms of Antarctic sea-ice as agents of primary production. Nature, Lond. 199: 1225-1257

Bunt, J. S. (1971). Microbial productivity in the polar regions. Symposia of the Society for General Microbiology XXI. Microbes and Biological productivity, p. 333-353

Cota, G. F. (1985). Photoadaptation of high arctic ice microalgae. Nature, Lond. 315: 219-222

Côté, B., Platt, T. (1983). Day-to-day variations in the springsummer photosynthetic parameters of coastal marine phytoplankton. Limnol. Oceanogr. 28: 320-344

Dring, M. J., Lüning, K. (1985). Emerson enhancement effect and quantum yield of photosynthesis for marine macroalgae in simulated underwater light fields. Mar. Biol. 87 109-117
Dubinsky, Z., Berman, T (1976). Light utilization efficiencies of phytoplankton in Lake Kinneret (Sea of Galilee). Limnol. Oceanogr. 21. 226-230

Dubinsky, Z., Berman, T., Schanz, F. (1984). Field experiments for in situ measurement of photosynthetic efficiency and quantum yield. J. Plankton Res. 6: 339-349

Dubinsky, Z., Falkowski, P. G., Wyman, K. (1986). Light harvesting and utilization by phytoplankton. Pl. Cell Physiol., Tokyo 27: 1335-1349

El-Sayed, S. Z., Biggs, D. C., Holm-Hansen, O. (1983). Phytoplankton standing crop, primary productivity, and nearsurface nitrogenous nutrient fields in the Ross Sea, Antarctica. Deep Sea Res. 30: 871-886

Emerson, R, Lewis, C. M. (1943). The dependence of the quantum efficiency of Chlorella photosynthesis on wave length of light. Am. J. Bot. 30: 165-178

Falkowski, P. G., Dubinsky, Z., Wyman, K. (1985). Growthirradiance relationships in phytoplankton. Limnol. Oceanogr. 30: 311-321

Fasham, M. J. R., Platt, T. (1983). Photosynthetic response of phytoplankton to light: a physiological model. Proc. R. Soc. Lond. B 219: 355-376

Fogg, G. E. (1977). Aquatic primary production in the Antarctic. Phil. Trans. R. Soc. Lond. B. biol. Sci. 279: 27-38

Gosselin, M., Legendre, L., Therriault, J., Demers, S. (1985). Physical control of the horizontal patchiness of sea ice microalgae (Southeastern Hudson Bay). EOS (Trans. Am. geophys. Un.) 66: 1278

Govindjee, R., Rabinowitch, E., Govindjee (1968). Maximum quantum yield and action spectra of photosynthesis and fluorescence in Chlorella. Biochim biophys. Acta 162: $539-544$

Grenfell, T. C., Maykut, G. A. (1977). The optical properties of ice and snow in the Arctic basin. J. Glaciol. 18: 445-463

Grenfell, T. C., Perovich, D. K. (1984). Spectral albedos of sea ice and incident solar irradiance in the Southern Beaufort Sea. J. geophys. Res. 89: 3573-3580

Grossi, S. M., Kottmeier, S. T., Moe, R. L., Taylor, G. T., Sullivan, C. W. (1987). Sea ice microbial communities. VI. Growth and primary production in bottom ice under graded snow cover. Mar. Ecol. Prog. Ser. 35: 153-164

Grossi, S. M., Sullivan, C. W (1985). Sea ice microbial communities. $V$. The vertical zonation of diatoms in an Antarctic fast ice community. J. Phycol. 21: 401-409

Højerslev, N. K. (1978). Daylight measurements appropriate for photosynthetic studies in natural sea waters. J. Cons. int. Explor. Mer 38: 131-146

Holm-Hansen, O., Lorenzen, C. J., Holmes, R. W., Strickland, J. D. H. (1965). Fluorometric determination of chlorophyll a. J. Cons. perm. int. Explor. Mer 30: 3-15

Horner, R. A., Schrader, G. C. (1982). Relative contributions of ice microalgae, phytoplankton, and benthic microalgae to primary production in nearshore regions of the Beaufort Sea. Arctic 35: 485-503

Hoshiai, T. (1981). Proliferation of ice microalgae in Syowa Station area, Antarctica. Mem. Nat. Inst. Polar Res. Ser. E. $34: 1-12$

Jacques, G. (1983). Some ecophysiological aspects of the Antarctic phytoplankton. Polar Biol. 2: 27-33

Jeffrey, S. W., Humphrey, G. F. (1975). New spectrophotometric equations for determining chlorophylls $a, b, c_{1}$ and $c_{2}$ in higher plants, microalgae and natural phytoplankton. Biochem. Physiol. Pflanz. 167: 191-194

Kiefer, D. A., Mitchell, B. G. (1983). A simple, steady state description of phytoplankton growth based on absorption cross section and quantum efficiency. Limnol. Oceanogr. 28: $770-776$ 
Kiefer, D. A., SooHoo, J. B. (1982). Spectral absorption by marine particles of coastal waters of Baja California. Limnol. Oceanogr. 27: 492-499

Kishino, M., Okami, N., Takahashi, M., Ichimura, S. (1986). Light utilization efficiency and quantum yield of phytoplankton in a thermally stratified sea. Limnol. Oceanogr 31: $557-566$

Kok, B. (1948). A critical consideration of the quantum efficiency of Chlorella photosynthesis. Enzymologia 13: 1-56

Kottmeier, S. T., Miller, M. A., Lizotte, M. P., Craft, L. L., Gulliksen, B., Sullivan, C. W. (1985). Ecology of sea-ice microbial communities during the 1984 winter-to-summer transition in McMurdo Sound, Antarctica. Antarctic J. U.S. 20: $128-130$

Lewis, E. L., Weeks, W F. (1970). Sea ice: some polar contrasts. In: Deacon, G. (ed.) Symposium on Antarctic ice and water masses. Scientific Committee on Antarctic Research, Tokyo, p. 23-34

Lewis, M. R., Horne, E. B. W., Cullen, J. J., Oakey, N. S., Platt T. (1984). Turbulent motions may control phytoplankton photosynthesis in the upper ocean. Nature, Lond. 311: $49-50$

Lewis, M. R., Smith, J. C. (1983). A small volume, shortincubation-time method for measurement of photosynthesis as a function of incident irradiance. Mar. Ecol. Prog. Ser. 13: 99-102

Lewis, M. R., Warnock, R. E., Irwin, B., Platt, T (1985a). Measuring photosynthetic action spectra of natural phytoplankton populations. J. Phycol. 21: 310-315

Lewis, M. R., Warnock, R. E., Platt, T (1985b). Absorption and photosynthetic action spectra for natural phytoplankton populations: implications for production in the open ocean. Limnol. Oceanogr. 30: 794-806

Lüning, K., Dring, M. J. (1985). Action spectra and spectral quantum yield of photosynthesis in marine macroalgae with thick and thin thalli. Mar. Biol. 87: 119-129

Manning, W. M., Juday, C., Wolf, M. (1938). Photosynthesis in Chlorella. Quantum efficiency and rate measurements in sunlight. J. Am. chem. Soc. 60: 274-278

Maykut, G. A., Grenfell, T C. (1975). The spectral distribution of light beneath first-year sea ice in the Arctic Ocean. Limnol. Oceanogr. 20: 554-563

Meffert, M. E., Overbeck, J. (1985). Dynamics of chlorophyll and photosynthesis in natural phytoplankton associations. II. Primary productivity, quantum yields and photosynthetic rates in small Northgerman lakes. Arch. Hydrobiol. 104 : 363-385

Mitchell, B. G., Kiefer, D. A. (1984). Determination of absorption and fluorescence excitation spectra for phytoplankton. In: Holm-Hansen, O., Bolis, L., Gilles, R. (ed.) Lecture notes on coastal and estuarine studies, Vol. 8. Marine phytoplankton and productivity. Springer-Verlag, New York, p. 157-169

Morel, A (1978). Available, usable, and stored radiant energy in relation to marine photosynthesis. Deep Sea Res. 25: 673-688

Neori, A., Holm-Hansen, O., Mitchell, B. G., Kiefer, D. A (1984). Photoadaptation marine phytoplankton. Changes in spectral absorption and excitation of chlorophyll a fluorescence. Pl. Physiol., Wash. 76: 518-524

$\mathrm{Ng}$, K. S., Bassham, J. A. (1968). The quantum requirement of photosynthesis in Chlorella. Biochirn. biophys. Acta 162 $254-264$

Palmisano, A. C., SooHoo, J. B., SooHoo, S. L., Kottmeier, S. T., Craft, L. L., Sullivan, C. W. (1986). Photoadaptation in Phaeocystis pouchetii advected beneath annual sea ice in McMurdo Sound, Antarctica. J. Plankton Res. 8: 891-906
Palmisano, A. C., SooHoo, J. B., Moe, R. L., Sullivan, C. W (1987a). Sea ice microbial communities. VII. Changes in under-ice spectral irradiance during the development of Antarctic sea ice microalgal communities. Mar. Ecol. Prog. Ser. 35: 165-173

Palmisano, A. C., SooHoo, J. B., Sullivan, C. W. (1987b). Effects of four environmental variables on photosynthesisirradiance relationships in Antarctic sea ice microalgae. Mar. Biol. 94: 299-306

Palmisano, A. C., SooHoo, J. B., Sullivan, C. W. (1985). Photosynthesis-irradiance relationships in sea ice microalgae from McMurdo Sound, Antarctica. J. Phycol. 21: 341-346

Palmisano, A. C., Sullivan, C. W. (1982). Physiology of sea ice diatoms. I. Response of three polar diatoms to a simulated summer-winter transition. J. Phycol. 18: 489-498

Palmisano, A. C., Sullivan, C. W (1983). Sea ice microbial communities (SIMCO). 1. Distribution, abundance, and primary production of ice microalgae in McMurdo Sound, Antarctica in 1980. Polar Biol. 2: 171-177

Perry, M. J., Talbot, M. C., Alberte, R. S. (1981). Photoadaptation in marine phytoplankton: response of the photosynthetic unit. Mar. Biol. 62: 91-101

Prezelin, B. B. (1981). Light reactions in photosynthesis. In Platt, T. (ed.) Physiological bases of phytoplankton ecology. Can. Bull. Fish. Aquat. Sci. 210: 1-43

Richardson, K., Beardall, J., Raven, J. A. (1983). Adaptation of unicellular microalgae to irradiance: an analysis of strategies. New Phytol. 93: 157-191

Roulet, N. T., Adams, W P. (1986). Spectral distribution of light under a subarctic winter lake cover. Hydrobiologia 134: 89-95

Siefermann-Harms, D. (1985). Carotenoids in photosynthesis I. Location in photosynthetic membranes and light-harvesting function. Biochim. biophys. Acta 811: 325-355

SooHoo, J. B., Kiefer, D. A., Collins, D. J., McDermid. I. S (1986). In vivo fluorescence excitation and absorption spectra of marine phytoplankton: I. Taxonomic characteristics and responses to photoadaptation. J. Plankton Res. 8: 197-214

Steemann-Nielsen, E. (1952). The use of radioactive carbon $\left({ }^{14} \mathrm{C}\right)$ for measuring organic production in the sea. J. Cons. perm. int. Explor. Mer 18: 117-140

Steemann-Nielsen, E. (1962). On the maximum quantity of plankton chlorophyll per surface unit of a lake or the sea. Int. Revue ges. Hydrobiol. 43: 330-338

Strickland, J. D. H., Parsons, T R. (1972). A practical handbook of seawater analysis, 2nd edn. Bull. Fish. Res. Bd Can. 167

Sullivan C. W. PaImisano, A. C. (1981). Sea ice microbial communities in McMurdo Sound, Antarctica. Antarct. J. U.S. 16: 126-127

Sullivan, C. W., Palmisano, A. C., Kottmeier, S. T., Grossi, S M., Moe, R. L., Taylor, G. T (1983). The influence of light on development and growth of sea-ice microbial communities in MCMurdo Sound. Antarct. J. U.S. 18: 100-102

Sullivan, C. W., Palmisano, A. C., Kottmeier, S. T., McGrathGrossi, S. M., Moe, R. L. (1985). The influence of light on growth and development of the sea-ice microbial community of McMurdo Sound. In: Siegfried, W. R., Condy, P. R. Laws, R. M. (ed.) Antarctic nutrient cycles and food webs. Proceedings of the 4 th SCAR Symposium on Antarctic biology. Springer-Verlag, Berlin, p. 78-83

Sullivan, C. W., Palmisano, A. C., SooHoo, J. B. (1984). Influence of sea ice and sea ice biota on downwelling irradiance and spectral composition of light in McMurdo Sound. In: Blizard, M. A. (ed.) Ocean optics VII. Proceedings Soc. Photooptical Instrumentation Engineers 489: 159-165 
Thomas, C. W. (1963). On the transfer of visible radiation through sea ice and snow. J. Glaciol. 4: 481-484

Tilzer, M. M. (1983). The importance of fractional light absorption by photosynthetic pigments for phytoplankton productivity in Lake Constance. Limnol. Oceanogr. 28: $833-846$

Tilzer, M. M. (1984). The quantum yield as a fundamental parameter controlling vertical photosynthetic profiles of phytoplankton in Lake Constance. Arch. Hydrobiol. 69 (Suppl.): 169-198

Tilzer, M. M., Bodungen, B. von, Smetacek, V. (1985). Light dependence of phytoplankton photosynthesis in the Antarctic Ocean: implications for regulating production. In: Siegfried, W. R., Condy, P. R., Laws, R. M. (ed.) Antarctic nutrient cycles and food webs. Proceedings of the 4 th SCAR Symposium on Antarctic biology. Springer-Verlag, Berlin, p. 60-69
Tilzer, M. M., Elbrächter, M., Gieskes, W. W., Beese, B. (1986). Light-temperature interactions in the control of photosynthesis in Antarctic phytoplankton. Polar Biol. 5: 105-111

Tyler, J. E. (ed.) (1966). Report on the second meeting of the Joint Group of experts on photosynthetic radiant energy. UNESCO Technical Papers in Marine Science, No. 2: 1-11

Tyler, J. E. (1975). The in situ quantum efficiency of natural phytoplankton populations. Limnol. Oceanogr. 20: 976-980

Welschmeyer, N. A., Lorenzen, C. J. (1981). Chlorophyllspecific photosynthesis and quantum efficiency at subsaturating light intensities. J. Phycol. 17: 283-293

Wood, R. D. (1975). Hydrobotanical methods. Univ. Park Press, Baltimore

Yentsch, C. S., Yentsch, C. M. (1979). Fluorescence spectral signatures: the characterization of phytoplankton populations by the use of excitation and emission spectra. J. mar. Res. 37: 471-483

This article was submitted to the editor; it was accepted for printing on April 28, 1987 